\title{
Article \\ Effects of Closing Cut Date and Nitrogen Fertilization on Seed Yield and Seed Quality in Two Novel Cultivars of Urochloa spp.
}

\author{
Weenaporn Juntasin ${ }^{1}\left(\right.$, , Yoshimi Imura ${ }^{2, *}$, Ichiro Nakamura ${ }^{2, *}$, Mohammad Amzad Hossain ${ }^{2}$, Sarayut Thaikua ${ }^{3}$, \\ Rattikan Poungkaew ${ }^{3}$ and Yasuhiro Kawamoto ${ }^{4}$ \\ 1 The United Graduate School of Agricultural Sciences, Kagoshima University, Kagoshima 890-0065, Japan; \\ weenaporn@gmail.com \\ 2 Faculty of Agriculture, University of the Ryukyus, Nishihara 903-0213, Japan; amzad@agr.u-ryukyu.ac.jp \\ 3 Nakhon Ratchasima Animal Nutrition Research and Development Center, Nakhon Ratchasima 30130, \\ Thailand; nok_tha@yahoo.com (S.T.); modem2554@gmail.com (R.P.) \\ 4 Okinawa Study Center, The Open University of Japan, Nishihara 903-0129, Japan; yasuk@agr.u-ryukyu.ac.jp \\ * Correspondence: yimura@agr.u-ryukyu.ac.jp (Y.I.); abreeder@agr.u-ryukyu.ac.jp (I.N.); \\ Tel.: +81-98-895-8765 (Y.I.); +81-98-895-8758 (I.N.)
}

Citation: Juntasin, W.; Imura, Y.; Nakamura, I.; Hossain, M.A.; Thaikua, S.; Poungkaew, R.; Kawamoto, Y. Effects of Closing Cut Date and Nitrogen Fertilization on Seed Yield and Seed Quality in Two Novel Cultivars of Urochloa spp. Agronomy 2022, 12, 513. https:// doi.org/10.3390/agronomy12020513

Received: 4 February 2022

Accepted: 16 February 2022

Published: 18 February 2022

Publisher's Note: MDPI stays neutral with regard to jurisdictional claims in published maps and institutional affiliations.

Copyright: (C) 2022 by the authors. Licensee MDPI, Basel, Switzerland. This article is an open access article distributed under the terms and conditions of the Creative Commons Attribution (CC BY) license (https:// creativecommons.org/licenses/by/ $4.0 /)$.

\begin{abstract}
Two field trials were conducted in Thailand to determine an appropriate closing cut date (CCD) and rate of nitrogen application (N-rate) to maximize seed yield and seed quality of the two novel cultivars (cv.) of Urochloa spp. (Synonym Brachiaria spp.), cv. 'OKI-1' (an open-pollinated tetraploid Urochloa ruziziensis (R. Germ. and C.M. Evrard) Crins originated from cv. 'Miyaokikokuichigou') and cv. 'Br-203' (U. ruziziensis cv. 'Miyaokikoku-ichigou' $\times$ U. hybrid cv. 'Mulato'). The following treatments were evaluated in this study: four CCDs (uncut, 15 June, 1 July, and 15 July) and four N-rates $(0,50,100$, and $150 \mathrm{~kg} / \mathrm{ha})$. The cv. 'OKI-1' showed somewhat differences in tiller number $/ \mathrm{m}^{2}(\mathrm{TN})$, fertile tiller percentage (FTP), inflorescence number/tiller (IN/T) and spikelet number/raceme (SN/R) with the CCD, while the cv. 'Br-203' showed only in SN/R. However, TN and SN/R were highest for 15 June, and FTP and IN/T were highest for 1 July in cv. 'OKI-1'. The cv. 'OKI-1' showed the highest total seed yield (TSY), pure seed yield (PSY), and pure germinated seed yield (PGSY) for 1 July, followed by 15 June, and the cv. 'Br-203' showed the highest TSY, PSY, and PGSY for 15 July, followed by 1 July. Nitrogen (N) fertilization showed a negative effect on TSY for both the cultivars due to the higher $\mathrm{N}$ content in the soil. Withholding $\mathrm{N}$ fertilizer, a CCD in late-June to early-July and early-July to mid-July is recommended for cv. 'OKI-1' and cv. 'Br-203', respectively.
\end{abstract}

Keywords: Brachiaria; closing date; cutting management; grass seed; nitrogen fertilizer; urea

\section{Introduction}

Urochloa (Synonym Brachiaria) is the most extensively distributed genus used for forage grass in the tropics, with approximately 100 species, including several commercially important species [1]. Ruminant livestock farmers use Urochloa spp. because of their high forage production and palatability for cattle, as well as their high nutritive value, adaptability, and environmental benefits (e.g., reducing soil erosion and greenhouse gas emissions) [2]. Urochloa spp. can be utilized as pasture, fodder in cut-and-carry systems, hay, silage, and mixed grass-legumes, among other things. Grasses from the genus Urochloa have been adopted to alleviate livestock feed shortages and improve the availability and quality of feeds. Furthermore, it can increase livestock productivity and farmers' revenue [3].

In this study, the optimal rate of nitrogen application (N-rate) and timing of closing cut date (CCD) were investigated in two novel candidate cultivars of Urochloa grass (Syn. Brachiaria grass). The one candidate cultivar (cv.) 'OKI-1', is an open-pollinated cultivar [4] that originated from recurrent selection through the evaluation of seed fertility and plant productivity among the base population of tetraploid Urochloa ruziziensis (R. Germ. and C.M. Evrard) Crins. cv. 'Miyaokikoku-ichigou' [5]. The cv. 'OKI-1' was obtained by the 
Department of Livestock Development in Thailand after pre-selection of the desired traits in Japan. The other candidate, cv. 'Br-203', is an apomictic hybrid produced by crossing a sexual maternal tetraploid parent of cv. 'Miyaokikoku-ichigou' (U. ruziziensis) [5]) with an apomictic paternal tetraploid parent of cv. 'Mulato' (U. ruziziensis $\times U$. brizantha (Hochst. ex A. Rich.) Stapf). The cv. 'OKI-1' had significantly higher in vitro dry matter digestibility compared with $U$. ruziziensis, cv. 'Mulato II' (U. ruziziensis $\times U$. decumbens (Stapf) R.D. Webster $\times U$. brizantha) and cv. 'Basilisk' (U. decumbens) [6]. In addition, the cv. 'Br203 ' had a high forage dry matter production $(19,200 \mathrm{~kg} / \mathrm{ha} /$ year on average over two years at five test sites in Thailand), excellent regrowth and extension, high palatability, relatively frequent flowering, and a seed ripening rate comparable to 'Basilisk' [7]. In a preliminary trial at the Lampang Animal Nutrition Research and Development Center, Lampang, Thailand (Lampang ANRDC) in 2017, cv. 'OKI-1' produced 15,800 kg/ha/year of forage dry matter yield. Widespread adoption of these cultivars requires that they are in demand and that they can be produced economically by increasing seed yield under good agronomic management.

The purpose of agricultural management for tropical grass seed production is to produce a synchronized, high-yielding seed crop by encouraging inflorescence development and restricting this development to a short emergence duration [8]; the closing cut is an important agronomic practice that is used to accomplish these aims. To allow the crop to flower properly, the closing cut should be scheduled carefully. Closing cuts that are too early will produce an excessive bulk of tall grass at harvest, which can increase the risk of lodging, disease occurrence, insect infestation, hinder inflorescence emergence and harvesting, and increase seed shattering losses $[9,10]$. On the other hand, closing cuts that are too late will remove many developing reproductive apices [11], ultimately decreasing inflorescence numbers and seed yields. In addition, the decreased leaf area from late regrowth can reduce seed yields due to a small inflorescence, even though the grass may be flowering abundantly when cut too late [12].

Hare et al. [9] reported that the final CCD is also very important for seed production in Urochloa hybrids in Thailand. The optimal time to carry out a final closing cut on the seed crops of cv. 'Mulato' and cv. 'Mulato II' was during July (mid-wet season). Optimal times for the closing cut have also been determined for $U$. ruziziensis [13] and cv. 'Mulato' [14] in Thailand. These studies recommend that the time of the final closing cut not be delayed past July, as the harvesting period of these cultivars is mid-November to early December. In addition, early closing cuts (May-June) and late closing cuts (September) either decreased seed yields markedly or resulted in no seeds being produced at all [15].

Nitrogen $(\mathrm{N})$ is a major factor limiting the production of grass seeds. Because $\mathrm{N}$ plays such a central role in determining grass seed yield, a key decision is when and how much $\mathrm{N}$ fertilizer should be applied [9]. The appropriate N-rate to optimize seed yield and quality in Urochloa hybrids [16], cv. 'Mulato' [14], U. ruziziensis [17,18], and Paspalum atratum [19] has been determined in Thailand. These studies found that the optimal N-rate varied from $40 \mathrm{~kg} / \mathrm{ha}$ to $400 \mathrm{~kg} / \mathrm{ha}$ due to several factors, such as soil nutrients, including N, soil moisture, changes in environmental parameters that affect crop development, and other aspects related to crop management. Research groups in different countries have undertaken studies on Urochloa; for example, in Brazil, studies have been conducted on $U$. brizantha [20] and $U$. decumbens [21], and in Benin, on $U$. ruziziensis [22]. Their results showed that N-rates for seed production ranged from $50 \mathrm{~kg} / \mathrm{ha}$ to $100 \mathrm{~kg} / \mathrm{ha}$.

The relationship between the CCD and the $\mathrm{N}$-rate has been investigated in $U$. ruziziensis by Wongsuwan [18], who found that a high pure germinated seed yield (PGSY) could be obtained using an N-rate of $150 \mathrm{~kg} \mathrm{~N} /$ ha and an early CCD (24 March 1997). Satjipanon et al. [17] reported that high seed yield with good quality was obtained in U. ruziziensis using a CCD on 14 August 1984 and 7 August 1985 with an N-rate of $400 \mathrm{~kg} \mathrm{~N} /$ ha. In other grass cultivars, such as cv. 'Mulato', the optimal CCD should not be later than $15 \mathrm{July}$, and $\mathrm{N}$ fertilizer should be applied at $100 \mathrm{~kg} \mathrm{~N} /$ ha thereafter [14]. 
Successful seed production of the two novel cultivars of Urochloa spp., cv. 'OKI-1' and cv. 'Br-203', could provide the basis for greatly increased forage production. To maximize seed production, an understanding of cultivation practices was required for widespread adoption of the new cultivars. With the knowledge of cultivation practices, including an optimal CCD and N-rate, seed producers can decide whether such an enterprise would be technically and economically viable. In addition, to provide useful information on the agricultural management of these grasses when they are promoted for planting in Thailand, two trials were designed to evaluate the effects of N-rate and CCD on seed yield and seed quality of both cultivars. They were examined under four CCDs (uncut, 15 June, 1 July, and 15 July) and four N-rates (0,50,100, and $150 \mathrm{~kg} \mathrm{~N} / \mathrm{ha})$ with four replications in a split-plot configuration in a randomized complete block design (RCBD).

\section{Materials and Methods}

\subsection{Location of the Experiment}

From May 2018 to February 2020, two field experiments were carried out at the Lampang Animal Nutrition Research and Development Center (Lampang ANRDC), Hang Chat, Lampang, Northern Thailand $\left(18.3^{\circ} \mathrm{N}, 99^{\circ} \mathrm{E} ; 320 \mathrm{~m}\right.$ asl). The soil belongs to the Renu soil series [23] (pp. 49-50). This soil has been classified according to USDA soil taxonomy as Ultisols, with sandy loam in the topsoil and sandy clay in the subsoil. The preliminary soil and post-harvest soil samples were collected at a depth of $0-15 \mathrm{~cm}$.

\subsection{Meteorological Data}

In 2018 and 2019, data on temperature, precipitation, rainy days, sunshine duration, relative humidity, and day length at Lampang ANRDC were collected from Hang Chat Agrometeorological Station in Hang Chat, Lampang, Thailand, which is about $2 \mathrm{~km}$ away from the experimental sites.

\subsection{Experimental Design and Treatments}

Trial 1: Effect of CCD and N-rate on seed yield, seed yield components, and seed quality in the candidate cultivar 'OKI-1' which originated from recurrent selection through the evaluation of seed fertility and plant productivity among the base population of tetraploid Urochloa ruziziensis (R. Germ. and C.M. Evrard) Crins. cv. 'Miyaokikoku-ichigou'.

The trial was conducted using a split-plot configuration in a randomized complete block design (RCBD) with four replicates (blocks). The main-plot treatments comprised four CCD treatments, i.e., uncut, cut on 15 June, 1 July, and 15 July, and sub-plot treatments within each main-plot included N-rates of 0,50,100, and $150 \mathrm{~kg} \mathrm{~N} /$ ha applied in the form of urea $(46 \% \mathrm{~N})$.

On 22 June 2018, the 30-day-old seedlings of cv. 'OKI-1' were planted in a plot size of $4 \times 5 \mathrm{~m}$ at a spacing of $1 \times 1 \mathrm{~m}$. At the time of planting, a basal fertilizer dressing $(312.5 \mathrm{~kg}$ NPK/ha, 15\%:15\%:15\%) was applied. To maintain uniform stands, any dead seedlings were replaced with fresh seedlings (grown at the same time as the deceased seedlings). Two months later, each tussock was loosely tied to a bamboo stake with plastic-coated wire to prevent its growth covering the ground. Weeds were controlled by removing them manually over the course of the experiment. The establishment year (2018) data were not analyzed or reported because all seedlings were planted on 22 June. After seed harvest, the grass cutting was performed on 28 December 2018 at $10 \mathrm{~cm}$ above ground level. The plant residues were then manually removed within one day after cutting and topdressing fertilizers (62.5 $\mathrm{kg} \mathrm{P} / \mathrm{ha}$ as single super phosphate and $62.5 \mathrm{~kg} \mathrm{~K} /$ ha as potassium chloride) were applied immediately. The effect of the CCD and N-rate was then analyzed in 2019 (the second year of the experiment). The closing cut occurred at the time specified, and the grass was cut with a sickle, as shown in Figure 1. After the closing cut of each treatment, topdressing with urea at a predefined rate was applied immediately to each tussock. 

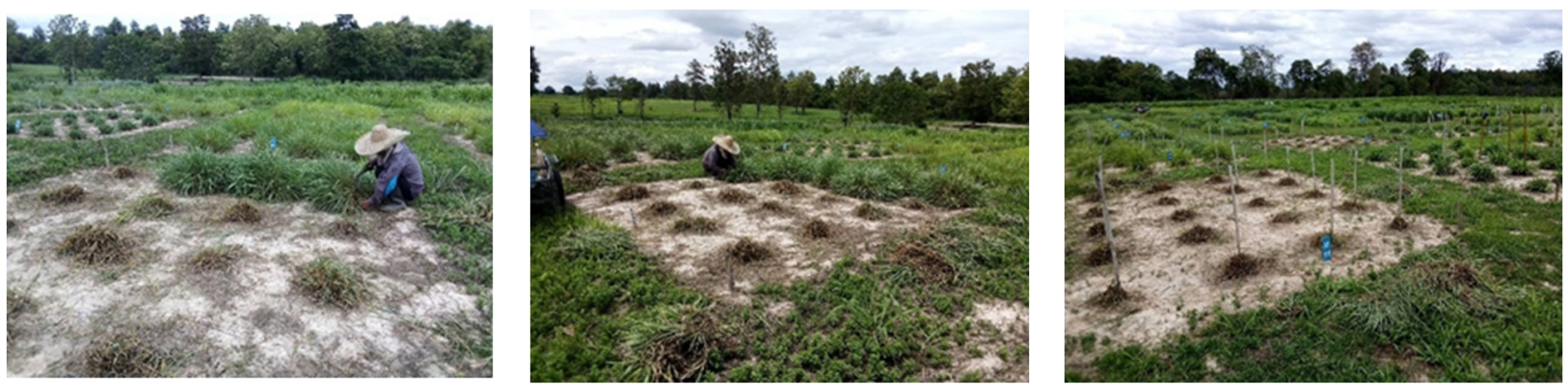

Figure 1. Grasses were cut by hand at the time specified for each closing cut date.

Trial 2: Effect of CCD and N-rate on seed yield, seed yield components, and seed quality in a cv. 'Br-203', an apomictic hybrid produced by crossing a sexual maternal tetraploid parent of cv. 'Miyaokikoku-ichigou' (Urochloa ruziziensis (R. Germ. and C.M. Evrard) Crins.) with an apomictic paternal tetraploid parent of cv. 'Mulato' (U. ruziziensis $\times$ U. brizantha (Hochst. ex A. Rich.) Stapf.)

The experimental site used for this trial was approximately $30 \mathrm{~m}$ away from the experimental site of Trial 1. For cv. 'Br-203', all of the treatments and methods, and the basal fertilizer rate used was equal to those applied for cv. 'OKI-1' in Trial 1.

\subsection{Data Collection and Seed Harvesting}

In all two trials, the beginning of the first flowering time was recorded for three randomly selected plants per plot once the first inflorescence had fully emerged from the sheath. Except for the border row, all of the inflorescences within each plot were harvested when the seeds were mature (late November to late December). At the time of harvest, three randomly selected plants in each plot were counted for the total number of tillers per plant. Fifteen randomly selected tillers on the three selected plants were counted for the number of inflorescences per tiller (IN/T). Fifteen randomly selected inflorescences on the three selected plants were counted for the number of racemes per inflorescence (RN/I). The number of spikelets per raceme (SN/R) was calculated by averaging the top, mid, and lower racemes of each inflorescence, which were chosen at random from among the fifteen inflorescences on the same three selected plants. Tiller fertility was calculated as the percentage of fertile tillers over the total number of tillers. When the seed was almost ripe, all of the inflorescences in each tussock were tied together as manageable bunches. The mature seeds were then shed from the manageable bunches and gathered with the use of a nylon net sheet positioned beneath the inflorescences. As shown in Figure 2, three fine mesh nylon net sheets per plot were used. The two nylon net sheets (A) each have a width of $1.2 \mathrm{~m}$ and a length of $5 \mathrm{~m}$. The other one is a nylon net sheet $(\mathrm{B})$ that is $1.2 \mathrm{~m}$ in width and $3 \mathrm{~m}$ in length. The bunches of grass plants, especially the inflorescences, were bent towards the nylon net sheets, following the red arrow directions. The experimental plots during seed harvesting are shown in Figure 3. When harvesting seeds, ripe seeds are threshed off the inflorescence by gently tapping. The ripened seeds fall into the nylon net sheet. The fallen seeds were scooped from the nylon net sheets and put into two fine mesh nylon bags that were prepared for collecting seeds in each plot. One bag was used for collecting seeds from two "A" nylon net sheets (border rows of grass plants), and the other bag was used for collecting seeds from a "B" nylon net sheet (six plants inside the plot). Only the collected seed from the " $\mathrm{B}$ " nylon net sheet in each plot was used to estimate seed yield, in order to avoid edge effects and bias caused by abiotic environmental factors that affected each grass plant (i.e., sunlight, wind, humidity). All bags of grass seed were sun-dried on the ground and hung for a few days after being hung for several days in the shade. Seeds were collected every four days except for the final collection, which was collected 15 days after the previous collection (a total of five times). The plots were harvested separately. 

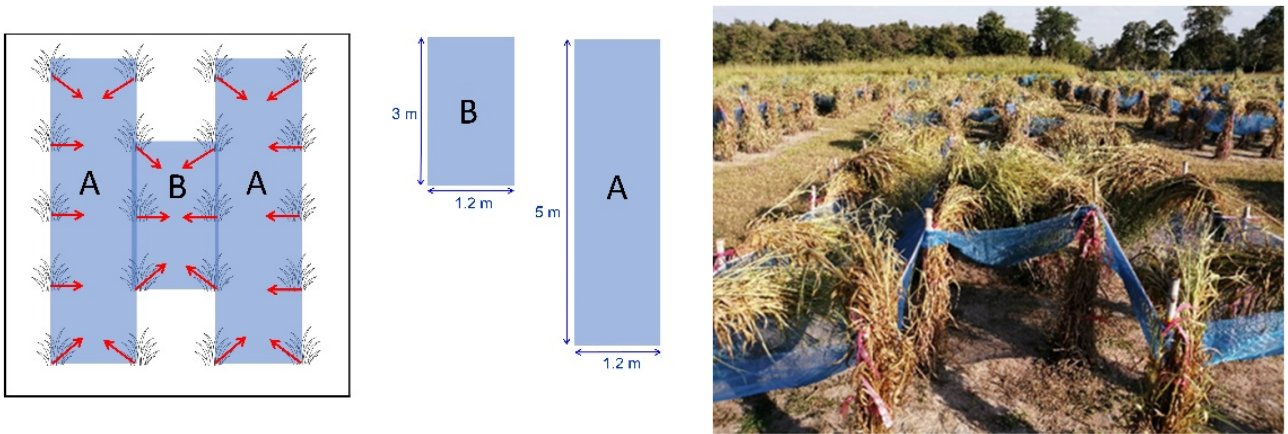

Figure 2. Stretching three nylon net sheets in the plot.
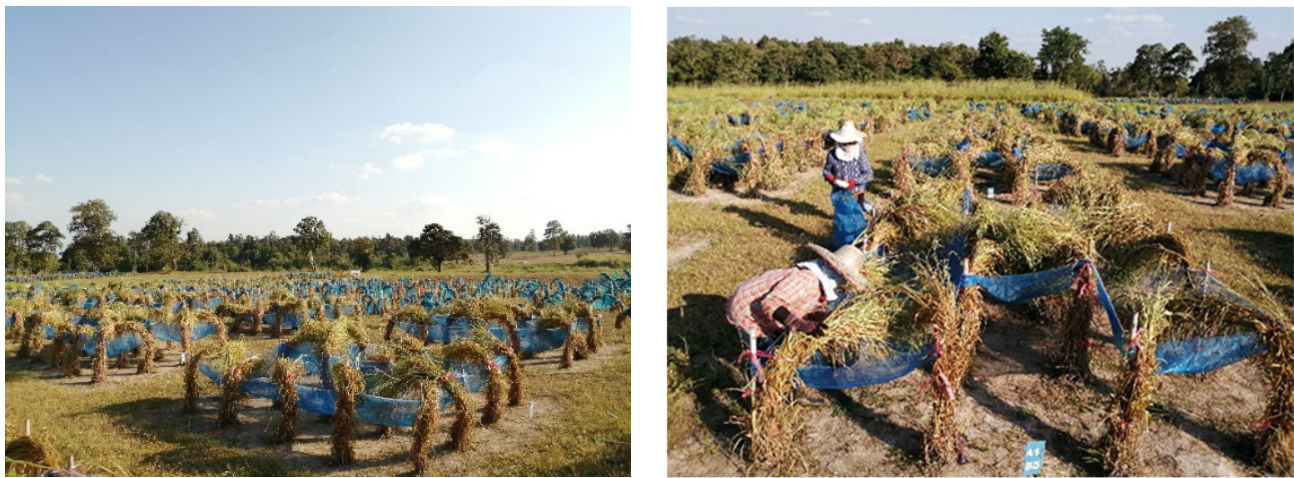

Figure 3. Experimental plots during seed harvesting.

\subsection{Seed Processing and Calculation of Secondary Attributes}

The harvested seeds were air-dried in the shade for several days before being sundried for a few days and then cleaned with a hand screen. Seeds with endosperm (filled seeds) were separated from the inert fraction and empty or light seeds using a South Dakota seed blower. The seed blower works by using airflow generated by a blower motor, and as that air passes through a column, the air lifts light, fluffy material or empty seed into the top beveled area of the column, while larger, heavier good seed stays at the bottom. Separations are accurately controlled by a calibrated valve cap at the top of the column. The filled seeds were then stored in paper bags at $25^{\circ} \mathrm{C}$ with a relative humidity of less than $50 \%$ until seed testing. Seed yield (SY) was recorded for each plot. Seed moisture content (SMC), seed purity percentage (PP), thousand seed weight (TSW), and seed germination percentage (GP) were assessed using the test methods of the International Seed Testing Association for U. ruziziensis [24]. TSW was measured using the weight of a pure-seed spikelet. Seed purity testing was performed by separating the pure seed fraction from inert materials and other seeds, and then separately weighing the pure seed fraction. The PP was calculated by multiplying the weight of pure seed by 100 and dividing it by the total weight of the sample. Germination tests were carried out 90 days after the seeds were harvested. SY was adjusted to $11 \% \mathrm{SMC}$. The tiller number $/ \mathrm{m}^{2}(\mathrm{TN})$, inflorescence number $/ \mathrm{m}^{2}(\mathrm{IN})$, the number of fertile tillers per plant, fertile tillers percentage (FTP), and filled seed percentage (FSP) were then calculated. The fertile tiller number $/ \mathrm{m}^{2}(\mathrm{FTN})^{*} 100 / \mathrm{TN}$ was used to determine the FTP, while the pure seed yield (PSY) was calculated as $\mathrm{SY}{ }^{*} \mathrm{PP} / 100$, and the pure germinated seed yield (PGSY) as PSY*GP/100.

\subsection{Statistical Analysis}

The ANOVA was performed using a split-plot design in RCBD with the four mainplot treatments and four sub-plot treatments replicated four times for yield and quality properties. Significant differences among the treatment means were tested by the least significant difference with the R software version 4.1.0 [25]. The Pearson's correlations 
were calculated for the CCD and N-rate with seed yield, seed yield components, and seed quality, and significant differences were declared among the means when $p<0.05$.

\section{Results and Discussion}

\subsection{Soil and Weather Conditions}

The chemical properties of preliminary soils at the experimental sites are shown in Table 1. Despite the fact that the soils at both experimental sites were acidic, had a low organic matter content $(<1 \%)$ and were deficient in essential minerals, the cultivars 'OKI- 1 ' and 'Br-203' demonstrated edaphic adaptation in terms of growth and productivity [26]. Our findings were confirmed by Rao et al. [27], who reported that most commercial Urochloa spp. are adaptable to a wide range of soil types; from poor, acidic soils to highly fertile, neutral soils.

Table 1. Chemical properties of preliminary soils collected from both experimental sites.

\begin{tabular}{|c|c|c|c|c|c|c|c|c|c|c|c|c|c|c|}
\hline \multirow{2}{*}{ Trial } & \multirow{2}{*}{$\mathrm{pH}$} & \multirow{2}{*}{$\begin{array}{l}\text { OM } \\
(\%)\end{array}$} & \multirow{2}{*}{$\begin{array}{c}\text { Total } \\
\text { N (\%) }\end{array}$} & \multicolumn{10}{|c|}{ Extractable (mg/kg) } & \multirow{2}{*}{$\begin{array}{c}\mathrm{EC} \\
(\mathrm{d} S / \mathrm{m})\end{array}$} \\
\hline & & & & $\mathbf{P}$ & $\mathbf{K}$ & $\mathrm{Ca}$ & Mg & $\mathbf{N a}$ & $\mathrm{S}$ & Mn & $\mathrm{Fe}$ & $\mathrm{Cu}$ & Zn & \\
\hline 1 & 5.39 & 0.67 & 0.03 & 0.89 & 39.84 & 614.38 & 36.66 & 12.44 & 3.03 & 14.15 & 55.70 & 0.24 & 0.07 & 0.83 \\
\hline 2 & 5.68 & 0.73 & 0.04 & 0.87 & 85.23 & 225.66 & 23.10 & 9.03 & 2.43 & 11.76 & 26.45 & 0.02 & 0.04 & 0.70 \\
\hline
\end{tabular}

Abbreviations: OM, organic matter; EC, electric conductivity.

In soil samples collected immediately after seed harvest, the $\mathrm{pH}$, phosphorus, and potassium levels were lower than before sowing, whereas the amounts of organic matter and $\mathrm{N}$ were slightly higher. The element values in each treatment were similar (Tables 2 and 3).

Table 2. Chemical properties of post-harvest soils in the experimental field in Trial 1.

\begin{tabular}{cccccc}
\hline $\begin{array}{c}\text { N-Rate } \\
\text { (kg N/ha) }\end{array}$ & pH & $\begin{array}{c}\text { Organic } \\
\text { Matter (\%) }\end{array}$ & Total N (\%) & \multicolumn{2}{c}{ Extractable (mg/kg) } \\
\cline { 5 - 6 } & & 1.53 & 0.08 & $\mathbf{P}$ & $\mathbf{K}$ \\
\hline 0 & 5.15 & 0.94 & 0.05 & 0.71 & 24.74 \\
100 & 4.76 & 0.85 & 0.04 & 0.67 & 25.24 \\
150 & 5.16 & 1.24 & 0.06 & 0.68 & 27.99 \\
\hline
\end{tabular}

Table 3. Chemical properties of post-harvest soils in the experimental field in Trial 2.

\begin{tabular}{cccccc}
\hline $\begin{array}{c}\text { N-Rate } \\
\text { (kg N/ha) }\end{array}$ & pH & $\begin{array}{c}\text { Organic } \\
\text { Matter (\%) }\end{array}$ & Total N (\%) & \multicolumn{2}{c}{ Extractable (mg/kg) } \\
\cline { 5 - 6 } & & 1.16 & 0.06 & $\mathbf{P}$ & $\mathbf{K}$ \\
\hline 0 & 5.12 & 1.23 & 0.06 & 0.71 & 39.15 \\
100 & 5.23 & 1.19 & 0.06 & 0.84 & 44.04 \\
150 & 5.15 & 1.16 & 0.06 & 0.82 & 34.46 \\
\hline
\end{tabular}

Increasing seed production in Urochloa spp. mostly relies on their adaptability to the climate. Seed set and pure live seed yield were substantially affected by weather conditions, particularly rainfall in the pre-heading stage [28]. Urochloa spp. are typically grown in areas with higher annual rainfall ( $>2000 \mathrm{~mm} /$ year), but they have been grown in areas with a minimum annual rainfall of roughly $1000 \mathrm{~mm}$ in Australia [29], and in some Urochloa hybrids, even in places with an annual rainfall as low as $700 \mathrm{~mm}$ and a dry season of 5-6 months [30]. During this study period (7 December 2018 to 24 December 2019), the annual rainfall was $855.9 \mathrm{~mm}$ with 96 rainy days, conforming to the range mentioned above (Figure 4A). The grasses received $112.47 \mathrm{~mm} / \mathrm{month}$ of rain in the growing period (June to November, 2019), which is considered sufficient for growth. Similarly, Bouathong 
et al. [16] reported that Urochloa grass requires $83-125 \mathrm{~mm}$ of rainfall each month during its growth period. In this study, the maximum rainfall occurred in August 2019 (330.1 mm with 24 rainy days). During that time, the grasses were regrowing after closed cutting and applying $\mathrm{N}$, which meant that the timing of rainfall was well suited for the growth of the Urochloa cultivars.

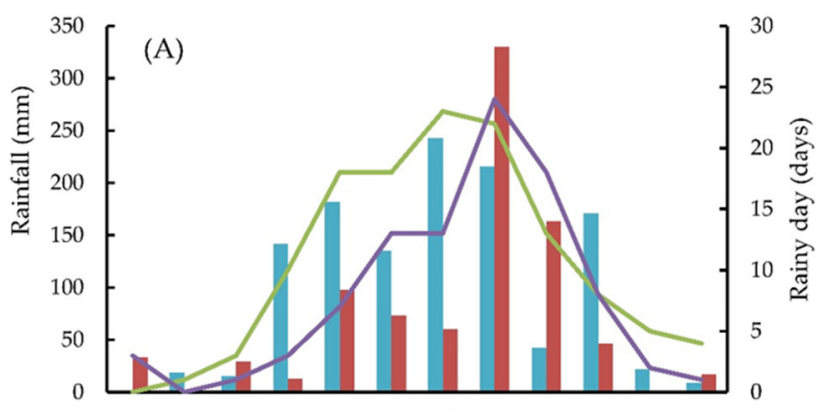

Jan Feb Mar Apr May Jun Jul Aug Sep Oct Nov Dec Month
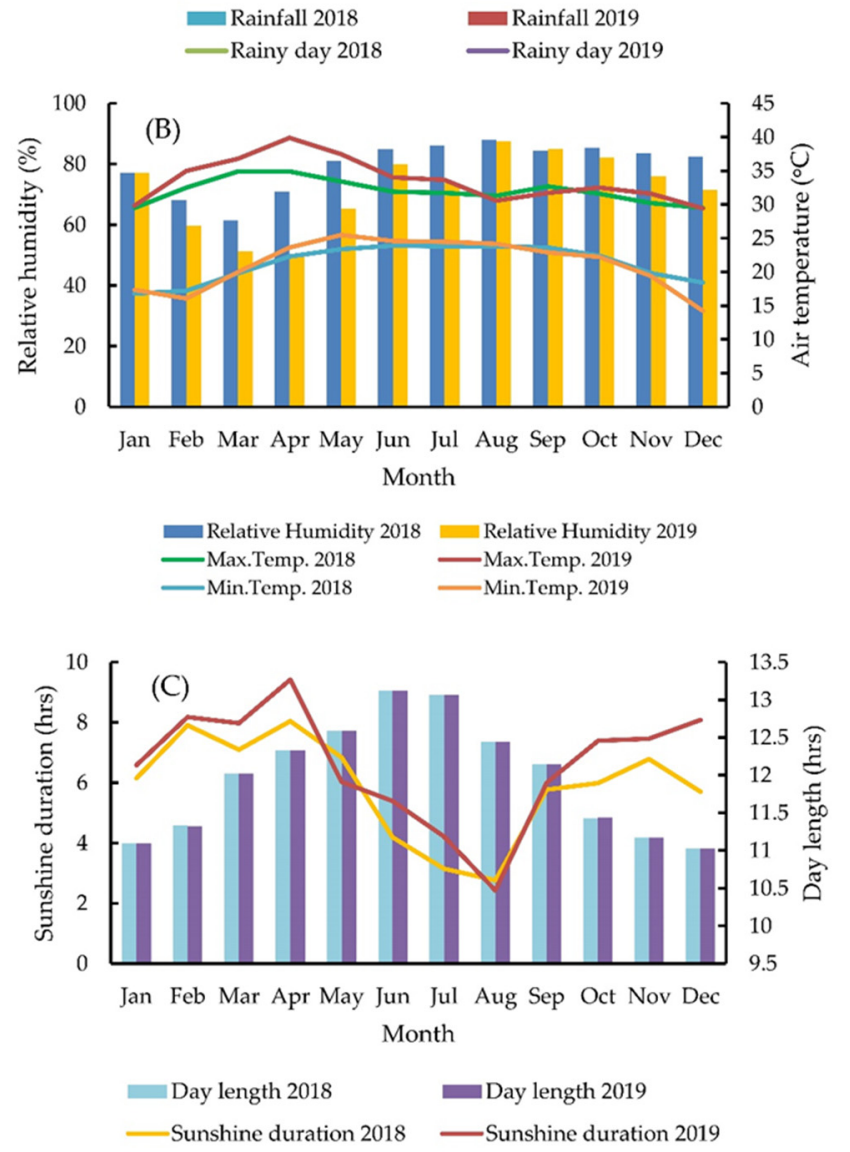

Figure 4. Meteorological, climatological, and geophysics data at the Lampang Animal Nutrition Research and Development Center in 2018 and 2019: (A) The average monthly rainfall and the number of rainy days in a month; (B) The monthly average relative humidity, the monthly average minimum, and the maximum temperature; (C) The monthly average day length and average daily sunshine duration.

It is well known that the optimal temperature and precipitation are necessary to increase pasture grass seed yield and quality [31]. In our trial, the monthly average relative humidity, the monthly average minimum, and the maximum temperature were shown in Figure 4B. During the experimental period, the average temperature and relative humidity in 2018 and 2019 were $26.6 \pm 1.9^{\circ} \mathrm{C}, 27.3 \pm 3.0^{\circ} \mathrm{C}$, and $79.5 \pm 8.3 \%, 71.6 \pm 12.6 \%$, 
respectively. Bouathong et al. [16] reported that the average temperature during their experiment was $27.3^{\circ} \mathrm{C}$, which was within the optimum range of $25-35^{\circ} \mathrm{C}$ for Urochloa species. This range was similar to that reported by Wongsuwan [32] (in [33]) for the optimum day- and night-time temperatures for $U$. ruziziensis, which were $33^{\circ} \mathrm{C}$ and $28^{\circ} \mathrm{C}$, respectively. From these reports, the average temperature at our study time is suitable for seed production of the two cultivars of Urochloa spp.

Figure $4 \mathrm{C}$ depicts the monthly average day length and average daily sunshine duration at the experimental sites. At the experimental sites, the average day length during the trial period was approximately $12 \mathrm{~h} /$ day, and the average sunshine duration was $6 \mathrm{~h} /$ day, with the shortest duration in August ( $3 \mathrm{~h} /$ day) and the longest duration in April ( $9 \mathrm{~h} /$ day). These conditions were most likely sufficient for Urochloa cultivars to grow and flower. This corroborates the findings of Wongsuwan [32], who reported that day length is crucial for triggering the reproductive development of $U$. ruziziensis in Thailand. They also found that the highest ruzi seed yields were obtained at 11-h day lengths compared with the longer day lengths $(14,13$ and $12 \mathrm{~h})$.

\subsection{Effects of CCD and N-Rate on Seed Yield, Seed Yield Components, and Seed Quality in the} Two Novel Cultivars of Urochloa spp.

In 2019, the period of cv. 'OKI-1' growth following the CCD to the beginning of the seed harvest in the treatments that were cut on 15 June, 1 July, and 15 July was 163 days, 148 days, and 133 days, respectively; the period of growth in the uncut treatment was 354 days.

For $\mathrm{cv}$. 'Br-203', the growth period from the beginning of each CCD till the beginning of harvest was longer than in cv. 'OKI-1' for three days: 166 days, 151 days, and 136 days for the CCD on 15 June, 1 July, and 15 July, respectively, and it was 357 days for the uncut treatment. Onset of flowering in both cultivars occurred at approximately the same time (13-29 October). The duration of seed harvesting was similar among all treatments in each cultivar (cv. 'OKI-1'; 25 November-24 December and cv. 'Br-203'; 28 November28 December).

In both trials, the analysis of variance showed that there were no significant interactions between CCD and N-rate for any of the traits measured, which is consistent with the findings of Nakmanee et al. [14] on cv. 'Mulato' in Northeast Thailand. Lodging was not observed in any of the treatments because all plants were tied to a bamboo stake inserted into the ground. Therefore, tiller death and seed shedding were not caused by lodging.

In both trials, several parameters, including seed yields, were not influenced by N-rate. This might be because of the incomplete $\mathrm{N}$ uptake and excessive rainfall after applying $\mathrm{N}$ fertilizer, which can cause soluble nitrate ions to be leached out of the rooting zone, diminishing $\mathrm{N}$ use efficiency [34]. $\mathrm{N}$ top-dressed as urea is expected to be lost through leaching and volatilization. Additionally, high temperatures also cause higher rates of $\mathrm{NH}_{3}$ volatilization because they increase the concentrations of $\mathrm{NH}_{3}$ dissolved in soil water [35]. Furthermore, because the soil at the experimental sites is a single-grain structure, $\mathrm{N}$ loss into the ground is possible. This is supported by the earlier studies [35,36], which reported that various soil and climate factors interact to affect urea volatilization, and $\mathrm{N}$ responses are also affected by climate, geographical factors, and soil factors, such as type, texture, drainage, $\mathrm{pH}$, fertility, moisture, and temperature. However, the efficiency of $\mathrm{N}$ application varies with plants, soil, seasons, climatic conditions, and application techniques. By understanding soil and climate factors that influence volatilization, avoiding applying urea in situations that may enhance volatilization or adopting best management practices to minimize the risk of loss is needed. Another possible reason for this is that when low soil fertility is caused by a deficiency of other nutrients rather than $\mathrm{N}$, responses to $\mathrm{N}$ will be improved once these nutrients are present in sufficient amounts [36]. Further study is required to evaluate the timing of $\mathrm{N}$ fertilizer application on seed yield, efficiency of $\mathrm{N}$ use, and apparent $\mathrm{N}$ efficiency of cv. 'OKI-1' and cv. 'Br-203'.

$\mathrm{N}$ could be applied to seedlings during the vegetative to spikelet initiation period. Adequate $\mathrm{N}$ from floral initiation to seedhead emergence can boost seed yield by improving 
tiller survival, increasing seedhead density, seedhead branching, floret differentiation, and seed size $[37,38]$. However, in our study, the $\mathrm{N}$ fertilizer was applied once in one dose after the closing cut immediately. This means plants do not get efficient fertilizer until the reproductive growth period. We have found that many tillers become yellowish from the start of seed harvest until the end of harvest. Furthermore, previous studies have shown that a split $\mathrm{N}$ application can improve nutrient use efficiency, promote optimal seed yields, and reduce nutrient loss $[39,40]$. Therefore, to achieve high seed yields in the two novel Urochloa cultivars, besides $\mathrm{N}$ fertilizer application after closing cut, applying $\mathrm{N}$ before flowering may be required.

3.2.1. Trial 1: Effect of CCD and N-Rate on Seed Yield, Seed Yield Components, and Seed Quality in Cultivar 'OKI-1'

As shown in Table 4, the CCD had a significant effect on seed yield, some seed yield components. The highest seed yield was obtained from the 1 July CCD, while the lowest seed yields were obtained from the uncut treatment and the 15 July CCD. Canto et al. [41] reported that crops with later CCD treatments and lower $\mathrm{N}$ nutrition rates, which caused the low leaf area, had a reduced ability to provide carbohydrates for seed production, along with a short period for the commencement of spikelets in new tillers. The results are consistent with an earlier study on CCD in cv. 'Mulato' grown in Thailand; the lowest PSY was obtained from the uncut plots and the delayed CCD (15 August) [14]. A study on Megathyrsus maximus cv. 'Mombaza' grown in Mexico by Joaquín et al. [42] also confirmed that the closing cut (precut) has a positive effect on the yield and quality of the guinea grass seed, with the highest yield being found with the CCD of July 20 when compared with the treatment without closing cut and the other delayed CCD treatments. However, this finding contrasted with a study on $U$. ruziziensis by Phaikaew et al. [15] in which the highest PSY was obtained in uncut plots. Similarly, Satjipanon et al. [17] showed that the highest PSY in the second year of the experiment was also obtained in uncut plots. As hypothesized, our experiments prove that the CCD was found to be particularly critical for seed production. This supports previous studies on Urochloa hybrids conducted in Thailand [9]. The proper time to implement a closing cut on the seed crops of cv. 'OKI-1' was 147-163 days (15 June-1 July) before seed harvest.

Table 4. Effect of closing cut date and nitrogen application rate on seed yield and seed yield components in cultivar 'OKI-1'.

\begin{tabular}{|c|c|c|c|c|c|c|c|c|}
\hline Treatment & $\begin{array}{c}\text { TSY } \\
\text { (kg/ha) }\end{array}$ & $\begin{array}{c}\text { TN } \\
\left(\mathrm{No} / \mathrm{m}^{2}\right)\end{array}$ & $\begin{array}{c}\text { FTN } \\
\left(\mathrm{No}^{2} / \mathrm{m}^{2}\right)\end{array}$ & $\begin{array}{c}\text { IN } \\
\left(\mathrm{No} . / \mathrm{m}^{2}\right)\end{array}$ & $\begin{array}{l}\text { FTP } \\
(\%)\end{array}$ & $\begin{array}{l}\text { IN/T } \\
\text { (No.) }\end{array}$ & $\begin{array}{l}\text { RN/I } \\
\text { (No.) }\end{array}$ & $\begin{array}{l}\text { SN/R } \\
\text { (No.) }\end{array}$ \\
\hline \multicolumn{9}{|l|}{ Closing cut date } \\
\hline Uncut & $484.96^{\mathrm{b}}$ & $94.62^{b}$ & 83.31 & 173.60 & $88.37^{a b}$ & $2.07^{a b}$ & 3.54 & $37.05^{a b}$ \\
\hline 15 June & $510.23^{a b}$ & $105.25^{\mathrm{a}}$ & 89.31 & 171.67 & $86.30^{a b}$ & $1.87^{\mathrm{b}}$ & 3.26 & $38.34^{\mathrm{a}}$ \\
\hline 1 July & $660.44^{\mathrm{a}}$ & $92.88^{b}$ & 85.90 & 182.65 & $92.81^{\mathrm{a}}$ & $2.14^{\mathrm{a}}$ & 3.61 & $34.79^{b}$ \\
\hline 15 July & $479.29^{b}$ & $99.69 \mathrm{ab}$ & 80.85 & 157.39 & $82.01^{b}$ & $1.90^{\mathrm{ab}}$ & 3.61 & $34.58^{b}$ \\
\hline CV $(\%)$ & 40.20 & 12.20 & 19.70 & 25.50 & 13.10 & 16.70 & 14.50 & 12.30 \\
\hline \multicolumn{9}{|l|}{$\begin{array}{c}\text { N-rate } \\
\text { (kg N/ha) }\end{array}$} \\
\hline 0 & 587.25 & $87.42^{b}$ & 80.96 & 174.03 & $93.01^{\mathrm{a}}$ & 2.13 & $3.73^{a}$ & 36.05 \\
\hline 50 & 562.57 & $100.94^{\mathrm{a}}$ & 89.04 & 175.19 & $88.45^{a b}$ & 1.95 & $3.40^{\mathrm{ab}}$ & 35.24 \\
\hline 100 & 443.62 & $100.15^{a}$ & 86.38 & 159.54 & $86.62^{a b}$ & 1.85 & $3.66^{\mathrm{a}}$ & 37.01 \\
\hline 150 & 541.47 & $103.94^{\mathrm{a}}$ & 83.00 & 176.54 & $81.41^{b}$ & 2.05 & $3.23^{b}$ & 36.44 \\
\hline CV $(\%)$ & 45.70 & 14.90 & 23.20 & 31.50 & 17.20 & 21.00 & 15.20 & 12.20 \\
\hline Mean & 533.73 & 98.11 & 84.84 & 171.33 & 87.37 & 2.00 & 3.51 & 36.19 \\
\hline $\mathrm{CCD} \times \mathrm{N}$-rate & ns & ns & ns & ns & ns & ns & ns & ns \\
\hline
\end{tabular}

Abbreviations: TSY, total seed yield; TN, tiller number per square meter; FTN, fertile tiller number per square meter; IN, inflorescence number per square meter; FTP, fertile tiller percentage; IN/T, inflorescence number per tiller; RN/I, raceme number per inflorescence; SN/R, spikelet number per raceme; ns, non-significant. Note: $\mathrm{a}, \mathrm{b}$ Means followed by different superscripts in each column indicate significant differences $(p<0.05)$. 
The total number of tillers, the percentage of tillers that went through the reproductive stage, and the number of reproductive tillers are the variables that are most highly correlated with seed production [43]. Several studies (e.g., [44-46]) have reported that optimum tiller density affects increased forage and seed yields. The poor seed yield of the uncut crop could be attributed to intra-plant competition because many tillers remained vegetative despite the otherwise favorable conditions for reproductive development. The closing cut increases seed yields by removing the shading effect of cumulative forage plants and allowing sunlight to penetrate the grass canopy, resulting in more rapid tiller emergence [38]. In addition, the closing cut is favorable to the competition for the reserves and photoassimilates in the leaves, stems, and young inflorescences of the emerged tillers, which affect the final mass of seed. The competition is influenced by the tiller hierarchy, i.e., tillers of smaller orders form heavier seeds since they receive more assimilates [9,47,48]. If plants are left uncut, they will grow to be overly tall, resulting in a decreased seed yield [12]. However, not much information has been specifically published on Urochloa grass with regard to tiller density and seed yield, or on the interrelationship between these two traits.

The closing cut on 15 June significantly increased TN and SN/R $(p<0.05)$; however, IN/T was the lowest for this treatment. The 1 July CCD produced the highest FTP and $\mathrm{IN} / \mathrm{T}$, but $\mathrm{SN} / \mathrm{R}$ was the lowest, the same as the 15 July CCD.

The low FTN and IN values found for the 15 July CCD were caused by the low fertility of late-emerging tillers. In addition, the 15 July closing cut decreases seed yields because many FTN are removed. The removal of many potential tillers reduces the number of inflorescences and results in inflorescences with fewer spikelets, even in the research carried out in Lolium spp. [10] These findings clearly show that FTP and IN had a positive relationship (Table 5). This corroborates with previous results [43], which reported that late cuts in relation to the cycle of forage grasses can have negative effects on the productivity of seeds, possibly by reducing the photosynthetic area and eliminating reproductive parts of the tiller. The increased IN in the closing cut treatments was found to be related to the increased seed yields. The study on Pennisetum spp. and Andropogon spp. by Mishra and Chatterjee [49] reported that a decrease in tiller fertility due to a delayed closing cut was strongly related to reduced seed yields, and it was quite possible that the apices of many of the early-forming tillers were destroyed. Additionally, a significantly lower SN/R was observed for the 1 July and 15 July CCDs in this trial. These findings were similar to those of Wongsuwan [18], who reported that the late closing cut severely depressed both floret numbers and fertilized seed numbers in $U$. ruziziensis.

Table 5. Correlation coefficients for seed yield, seed components and CCD in cultivar 'OKI-1'.

\begin{tabular}{|c|c|c|c|c|c|c|c|c|}
\hline Traits & CCD & TSY & TN & FTN & IN & FTP & IN/T & RN/I \\
\hline TSY & -0.3600 & & & & & & & \\
\hline $\mathrm{TN}$ & -0.3668 & -0.5223 & & & & & & \\
\hline FTN & -0.1675 & 0.3454 & 0.4199 & & & & & \\
\hline IN & 0.2100 & 0.7733 & -0.4966 & 0.5782 & & & & \\
\hline FTP & 0.1931 & 0.8311 & -0.6407 & 0.4271 & $0.9817^{* *}$ & & & \\
\hline $\mathrm{IN} / \mathrm{T}$ & 0.3686 & 0.6802 & $-0.9443 *$ & -0.0990 & 0.7543 & 0.8555 & & \\
\hline $\mathrm{RN} / \mathrm{I}$ & 0.0378 & 0.2722 & -0.8100 & -0.8042 & -0.0536 & 0.1361 & 0.5890 & \\
\hline \multirow[t]{2}{*}{$\mathrm{SN} / \mathrm{R}$} & 0.4129 & -0.3906 & 0.5640 & 0.6699 & 0.1631 & -0.0174 & -0.3566 & $-0.8943^{*}$ \\
\hline & & $\begin{array}{l}\text { Abbrevia } \\
\text { tiller num } \\
\text { infloresce } \\
\text { Values } \mathrm{w} \\
0.878339\end{array}$ & $\begin{array}{l}\text { CCD, closir } \\
\text { per square m } \\
\text { umber per til } \\
\text { t asterisks ar } \\
* \text { correlation }\end{array}$ & $\begin{array}{l}\text { ut date; TS } \\
\text { IN, inflore } \\
\text { RN/I, racem } \\
\text { t significan } \\
\text { gnificant at }\end{array}$ & $\begin{array}{l}\text { al seed yiel } \\
\text { e number } \mathrm{p} \\
\text { mber per in } \\
\text { orrelation is } \\
01 \text { level (tw }\end{array}$ & $\begin{array}{l}\mathrm{J} \text {, tiller nur } \\
\text { uare meter } \\
\text { cence; } \mathrm{SN} / \\
\text { ificant at } \mathrm{t} \\
\text { ed), } p<0.0\end{array}$ & $\begin{array}{l}\text { per square } \\
\text { fertile tille } \\
\text { kelet numbe } \\
5 \text { level (twc } \\
958735 \text {. }\end{array}$ & $\begin{array}{l}\text { er; FTN, fertil } \\
\text { rcentage; IN } / \\
\text { r raceme. Note } \\
\text { led), } p<0.05=\end{array}$ \\
\hline
\end{tabular}

The seed quality of cv. 'OKI-1' was also affected by the CCD. The highest FSP, TSW, and PP were obtained from the 1 July closing cut (Table 6). The lowest TSW was observed when the closing cut was delayed until 15 July. The uncut treatment had significantly reduced FSP and PP values $(p<0.05)$ when compared with the 1 July treatment. The 
obviously low PP and GP values were observed in the uncut and 15 July CCD treatments when compared with the 15 June and 1 July CCDs. These low values also led to low PSY and PGSY significantly $(p<0.05)$. Although a significant difference was observed in PP, seed purity was very high in each treatment due to good management from seed setting until seed harvesting and cleaning. The most marked effect of the CCD on these seed quality attributes in OKI-1 was gained from the CCD on 1 July, as shown in Table 6. In this trial, the 15 July CCD had a lower TSW than the other CCD treatments. This tendency was similar to that observed in seed quality in P. atratum in Thailand in that a May-July CCD had a higher TSW than an August CCD [11], and similar to cv. 'Mulato' in Thailand [14], where TSW decreased following the delayed CCD (comparing between 15 June, 15 July and 15 August). This was due to the duration of growth after cutting until flowering being shorter than it was in the other treatments, which caused a decrease in seed size [45].

Table 6. Effect of closing cut date and nitrogen application rate on seed quality in cultivar 'OKI-1'.

\begin{tabular}{ccccccc}
\hline Treatment & $\begin{array}{c}\text { FSP } \\
(\%)\end{array}$ & $\begin{array}{c}\text { TSW } \\
(\mathbf{g})\end{array}$ & $\begin{array}{c}\text { PP } \\
\mathbf{( \% )}\end{array}$ & $\begin{array}{c}\text { PSY } \\
(\mathbf{k g} / \mathbf{h a})\end{array}$ & $\begin{array}{c}\text { GP } \\
(\%)\end{array}$ & $\begin{array}{c}\text { PGSY } \\
\text { (kg/ha) }\end{array}$ \\
\hline $\begin{array}{c}\text { Closing cut } \\
\text { date }\end{array}$ & & & & & & \\
Uncut & $24.56^{\mathrm{b}}$ & $8.42^{\mathrm{ab}}$ & $98.73^{\mathrm{b}}$ & $478.82^{\mathrm{b}}$ & 91.62 & $439.71^{\mathrm{b}}$ \\
15 June & $28.55^{\mathrm{ab}}$ & $8.51^{\mathrm{ab}}$ & $99.00^{\mathrm{ab}}$ & $504.87^{\mathrm{ab}}$ & 93.02 & $474.05^{\mathrm{ab}}$ \\
1 July & $35.08^{\mathrm{a}}$ & $8.58^{\mathrm{a}}$ & $99.22^{\mathrm{a}}$ & $654.97^{\mathrm{a}}$ & 93.28 & $611.31^{\mathrm{a}}$ \\
15 July & $28.70^{\mathrm{ab}}$ & $8.32^{\mathrm{b}}$ & $98.72^{\mathrm{b}}$ & $473.39^{\mathrm{b}}$ & 91.38 & $432.55^{\mathrm{b}}$ \\
CV (\%) & 28.40 & 3.40 & 0.50 & 40.40 & 3.50 & 41.40 \\
N-rate (kg & & & & & & \\
N/ha) & & & & & & \\
0 & $33.52^{\mathrm{a}}$ & $8.72^{\mathrm{a}}$ & $99.30^{\mathrm{a}}$ & 582.89 & 92.55 & 539.26 \\
50 & $30.03^{\mathrm{ab}}$ & $8.49^{\mathrm{ab}}$ & $98.47^{\mathrm{b}}$ & 553.68 & 92.97 & 514.97 \\
100 & $27.52^{\mathrm{b}}$ & $8.34^{\mathrm{b}}$ & $98.99^{\mathrm{ab}}$ & 439.62 & 92.31 & 408.71 \\
150 & $25.82^{\mathrm{b}}$ & $8.29^{\mathrm{b}}$ & $98.91^{\mathrm{ab}}$ & 535.86 & 91.47 & 494.68 \\
CV (\%) & 21.50 & 4.30 & 0.80 & 45.50 & 5.10 & 46.30 \\
\hline Mean & 29.22 & 8.46 & 98.92 & 528.01 & 92.32 & 489.40 \\
CCD $\times$ N-rate & $\mathrm{ns}$ & $\mathrm{ns}$ & $\mathrm{ns}$ & $\mathrm{ns}$ & $\mathrm{ns}$ & $\mathrm{ns}$ \\
\hline
\end{tabular}

Abbreviations: FSP, filled seed percentage; TSW, thousand seed weight; PP, purity percentage; PSY, pure seed yield, GP, germination percentage; PGSY, pure germinated seed yield; ns, non-significant. Note: ${ }^{a, b}$ Means followed by different superscripts in each column indicate significant differences $(p<0.05)$.

The CCD was not significantly correlated with all the seed quality attributes in cv. 'OKI-1' ( $p>0.05)$ (Table 7). The reasons for the low PSY and PGSY were related to the uncut treatment's having a low FSP and a low PSY, because the FSP was positively correlated with PSY and PGSY (Table 7).

Table 7. Correlation coefficients for seed quality and CCD in cultivar 'OKI-1'.

\begin{tabular}{ccccccc}
\hline Traits & CCD & FSP & TSW & PP & PSY & GP \\
\hline FSP & -0.7112 & & & & & \\
TSW & -0.1391 & 0.6318 & & & & \\
PP & -0.4614 & 0.8609 & $0.9326^{*}$ & & & \\
PSY & -0.3621 & $0.9089^{*}$ & 0.8176 & $0.9161^{*}$ & & \\
GP & -0.4023 & 0.7084 & $0.9515^{*}$ & $0.9596^{* *}$ & 0.7725 & \\
PGSY & -0.3711 & $0.9072^{*}$ & 0.8460 & $0.9376^{*}$ & $0.9983^{* *}$ & 0.8082 \\
\hline
\end{tabular}

Abbreviations: CCD, closing cut date; FSP, filled seed percentage; TSW, thousand seed weight; PP, purity percentage; PSY, pure seed yield; GP, germination percentage; PGSY, pure germinated seed yield. Note: Values without asterisks are not significant, ${ }^{*}$ correlation is significant at the 0.05 level (two-tailed), $p<0.05=0.878339$ and ${ }^{* *}$ correlation is significant at the 0.01 level (two-tailed), $p<0.01=0.958735$.

The N-rate had no significant effect on the seed yields in cv. 'OKI-1' (Table 4). However, the N-rate had a significant $(p<0.05)$ effect on seed yield components; the applied $\mathrm{N}$ 
enhanced TN, and increasing N-rates decreased FTP. On the other hand, the lowest RN/I value was observed at the highest $\mathrm{N}$-rate $(150 \mathrm{~kg} \mathrm{~N} / \mathrm{ha})$. This is in contradiction with earlier findings $[8,50]$, which reported that the positive response of tropical and subtropical grasses to $\mathrm{N}$ fertilizer was primarily due to an increase in the number of fertile tillers, increased spike length, and an increase in the number of spikelets/spikes.

The N-rate of $150 \mathrm{~kg} \mathrm{~N} /$ ha produced approximately $16 \%$ more TN than the control treatment. Our results were similar to those obtained in previous studies on $U$. decumbens and $U$. ruziziensis, which showed that $\mathrm{TN}$ increased with an increase in the N-rate $[20,21]$. Wongsuwan [18] also found that the addition of 150 and $250 \mathrm{~kg} \mathrm{~N} /$ ha significantly increased total reproductive tiller numbers. In our study, the application of $150 \mathrm{~kg} \mathrm{~N} / \mathrm{ha}$ to cv. 'OKI-1' decreased FTP and RN/I by approximately $13 \%$ and $10 \%$, respectively, compared with the control treatment. The strong and significant negative correlation between $\mathrm{N}$-rate and FTP was found only in cv. 'OKI-1' (Table 8). As reported by Langer [51], the number of fertile tillers is not necessarily related to increased $\mathrm{N}$ application levels, likely because of unfavorable partitioning of assimilates between leaves for growth and seed production, greater competition for assimilates in a lodged crop, and possibly due to inadequate pollination.

Table 8. Correlation coefficients for seed yield, seed components and N-rate in cultivar 'OKI-1'.

\begin{tabular}{|c|c|c|c|c|c|c|c|c|}
\hline Traits & N-Rate & TSY & $\mathrm{TN}$ & FTN & IN & FTP & IN/T & RN/I \\
\hline TSY & -0.5259 & & & & & & & \\
\hline $\mathrm{TN}$ & 0.8610 & -0.4558 & & & & & & \\
\hline FTN & 0.1248 & -0.3545 & 0.5828 & & & & & \\
\hline IN & -0.1323 & 0.9084 * & -0.0668 & -0.2586 & & & & \\
\hline FTP & $-0.9856^{* *}$ & 0.3914 & -0.8884 * & -0.1462 & -0.0247 & & & \\
\hline $\mathrm{IN} / \mathrm{T}$ & -0.3612 & 0.8466 & -0.5798 & -0.7948 & 0.7571 & 0.2823 & & \\
\hline $\mathrm{RN} / \mathrm{I}$ & -0.6904 & -0.1618 & -0.7842 & -0.2286 & -0.5548 & 0.8025 & -0.0296 & \\
\hline $\mathrm{SN} / \mathrm{R}$ & 0.5155 & -0.7649 & 0.1253 & -0.3261 & -0.7035 & -0.3715 & -0.3048 & 0.2403 \\
\hline
\end{tabular}

Abbreviations: N-rate, rate of nitrogen application; CCD, closing cut date; TSY, total seed yield; TN, tiller number per square meter; FTN, fertile tiller number per square meter; IN, inflorescence number per square meter; FTP, fertile tiller percentage; IN/T, inflorescence number per tiller; RN/I, raceme number per inflorescence; SN/R, spikelet number per raceme. Note: Values without asterisks are not significant, ${ }^{*}$ correlation is significant at the 0.05 level (two-tailed), $p<0.05=0.878339$ and ${ }^{* *}$ correlation is significant at the 0.01 level (two-tailed), $p<0.01=$ 0.958735 .

Additionally, $\mathrm{N}$ application significantly decreased the seed quality attributes, such as FSP, TSW, and PP ( $p<0.05)$ (Table 6). According to our findings, increasing the N-rate gradually decreased FSP and TSW in cv. 'OKI-1'. A negative correlation was observed between seed quality and N-rate in cv. 'OKI-1', as shown in Table 9.

Table 9. Correlation coefficients for seed quality and N-rate in cultivar 'OKI-1'.

\begin{tabular}{ccccccc}
\hline Traits & N-Rate & FSP & TSW & PP & PSY & GP \\
\hline FSP & $-0.9880^{* *}$ & & & & & \\
TSW & $-0.9630^{* *}$ & $0.9929^{* *}$ & & & & \\
PP & -0.2450 & 0.3445 & 0.3963 & & & \\
PSY & -0.5310 & 0.6107 & 0.6767 & 0.0477 & & \\
GP & -0.7968 & 0.6971 & 0.6148 & -0.3038 & 0.2000 & \\
PGSY & -0.5455 & 0.6214 & 0.6845 & 0.0298 & $0.9996^{* *}$ & 0.2267 \\
\hline
\end{tabular}

Abbreviations: N-rate, rate of nitrogen application; FSP, filled seed percentage; TSW, thousand seed weight; PP, purity percentage; PSY, pure seed yield; GP, germination percentage; PGSY, pure germinated seed yield. Note: Values without asterisks are not significant, ${ }^{* *}$ correlation is significant at the 0.01 level (two-tailed), $p<0.01=$ 0.958735 .

3.2.2. Trial 2: Effect of CCD and N-Rate on Seed Yield, Seed Yield Components and Seed Quality in Cultivar 'Br-203'

The effect of CCD on seed yield and seed yield components was not significant $(p>0.05)$, except for SN/R as shown in Table 10. The results could be explained by the fact 
that all tussocks of grass were supported with bamboo stakes and tied the inflorescences to the stakes with plastic coated wire, resulting in no tiller damage and no seed loss due to lodging. Conversely, in several previous studies [11,19], the lower seed yields in earlier closed crops were observed to be caused by severe lodging at seed harvest. The uncut treatment had the highest $\mathrm{SN} / \mathrm{R}$, while the lowest $\mathrm{SN} / \mathrm{R}$ was shown in the delayed closing cut (15 July). Moreover, a delay in the CCD likely caused a decrease in TN, FTN, FTP, and RN/I. This supports previous findings in P. atratum grown in Thailand [11], which reported that inflorescences produced from plants cut in August (delayed closing cut) had fewer racemes per inflorescence and generally fewer spikelets per raceme compared with inflorescences from plants cut earlier. Since the last CCD of the study was on 15 July, we were unable to clearly indicate the relationships between the delayed CCD and the seed yields. However, the CCD treatments applied in this study corresponds to the recommended closing cut period for cv. 'Mulato' and cv. 'Mulato II' seed crops in Thailand (early July-early August) [9] as well as the recommendation of CCD for U. ruziziensis [15] and $P$. atratum $[11,19]$ should also be performed in early July-early August.

Table 10. Effect of closing cut date and nitrogen application rate on seed yield and seed yield components in cultivar 'Br-203'.

\begin{tabular}{|c|c|c|c|c|c|c|c|c|}
\hline Treatment & $\begin{array}{c}\text { TSY } \\
\text { (kg/ha) }\end{array}$ & $\begin{array}{c}\text { TN } \\
\left(\text { no. } / \mathrm{m}^{2}\right)\end{array}$ & $\begin{array}{c}\text { FTN } \\
\left(\text { no. } / \mathrm{m}^{2}\right)\end{array}$ & $\begin{array}{c}\text { IN } \\
\left(\text { no. } / \mathrm{m}^{2}\right)\end{array}$ & $\begin{array}{l}\text { FTP } \\
(\%)\end{array}$ & $\begin{array}{l}\text { IN/T } \\
\text { (no.) }\end{array}$ & $\begin{array}{l}\text { RN/I } \\
\text { (no.) }\end{array}$ & $\begin{array}{c}\text { SN/R } \\
\text { (no.) }\end{array}$ \\
\hline \multicolumn{9}{|l|}{ Closing cut date } \\
\hline Uncut & 303.17 & 163.60 & 127.46 & 315.00 & 76.86 & 2.30 & 3.42 & $36.33^{a}$ \\
\hline 15 June & 298.85 & 173.81 & 126.25 & 293.93 & 73.73 & 2.28 & 3.39 & $34.62^{\mathrm{ab}}$ \\
\hline 1 July & 339.76 & 163.12 & 119.58 & 308.38 & 71.93 & 2.29 & 3.31 & $34.45^{\mathrm{ab}}$ \\
\hline 15 July & 361.02 & 162.75 & 115.42 & 327.30 & 69.56 & 2.36 & 3.05 & $30.77^{b}$ \\
\hline CV $(\%)$ & 45.30 & 12.80 & 18.80 & 32.20 & 21.40 & 19.30 & 21.50 & 14.60 \\
\hline \multicolumn{9}{|l|}{ N-rate (kg N/ha) } \\
\hline 0 & 411.91 & 158.92 & 120.12 & 293.32 & 75.83 & 2.17 & 3.29 & 32.21 \\
\hline 50 & 387.20 & 161.73 & 118.71 & 293.64 & 72.16 & 2.27 & 3.07 & 35.38 \\
\hline 100 & 302.22 & 167.85 & 114.58 & 310.15 & 67.00 & 2.38 & 3.30 & 32.83 \\
\hline 150 & 374.70 & 174.79 & 135.29 & 347.50 & 77.09 & 2.41 & 3.51 & 35.75 \\
\hline CV $(\%)$ & 63.90 & 17.50 & 42.70 & 69.40 & 36.80 & 49.20 & 23.90 & 16.40 \\
\hline Mean & 325.70 & 165.82 & 122.18 & 311.15 & 73.02 & 2.31 & 3.29 & 34.04 \\
\hline $\mathrm{CCD} \times \mathrm{N}$-rate & ns & ns & ns & ns & ns & ns & ns & ns \\
\hline
\end{tabular}

Abbreviations: TSY, total seed yield; TN, tiller number per square meter; FTN, fertile tiller number per square meter; IN, inflorescence number per square meter; FTP, fertile tiller percentage; IN/T, inflorescence number per tiller; RN/I, raceme number per inflorescence; SN/R, spikelet number per raceme; ns, non-significant. Note: $\mathrm{a}, \mathrm{b}$ Means followed by different superscripts in each column indicate significant differences $(p<0.05)$.

A significant correlation $(p<0.05)$ between CCD and FTP in the cv. 'Br-203' is shown in Table 11. TSY has a positive correlation with IN and IN/T while having a negative correlation with other seed components.

Table 11. Correlation coefficients for seed yield, seed components and CCD in cultivar 'Br-203'.

\begin{tabular}{ccccccc}
\hline Traits & CCD & TSY & TN & FTN & IN & FTP \\
\hline TSY & -0.6000 & & & & & \\
TN & -0.1754 & -0.6503 & & & & \\
FTN & 0.7072 & $-0.9893^{* *}$ & 0.5337 & & & \\
IN & 0.0675 & 0.7285 & -0.8455 & -0.6401 & & \\
FTP & $0.8914^{*}$ & $-0.8821^{*}$ & 0.2174 & $0.9413^{*}$ & -0.3919 & -0.6356 \\
IN/T & -0.2454 & 0.7815 & -0.5508 & -0.7522 & $0.8946^{*}$ & $0.8879 *$ \\
RN/I & 0.5993 & $-0.9167^{*}$ & 0.4430 & $0.9289^{*}$ & -0.7345 & $-0.9195^{*}$ \\
SN/R & 0.7261 & -0.8437 & 0.2263 & $0.8892^{*}$ & -0.5645 & $0.9288^{*}$ \\
\hline
\end{tabular}

Abbreviations: CCD, closing cut date; TSY, total seed yield; TN, tiller number per square meter; FTN, fertile tiller number per square meter; IN, inflorescence number per square meter; FTP, fertile tiller percentage; IN/T, inflorescence number per tiller; RN/I, raceme number per inflorescence; $\mathrm{SN} / \mathrm{R}$, spikelet number per raceme. Note: Values without asterisks are not significant, * correlation is significant at the 0.05 level (two-tailed), $p<0.05=$ 0.878339 and ${ }^{* *}$ correlation is significant at the 0.01 level (two-tailed), $p<0.01=0.958735$. 
As shown in Table 12, no seed quality attributes were affected by CCD. However, CCD had a significant correlation with FSP in cv. 'Br-203' (Table 13).

Table 12. Effect of closing cut date and nitrogen application rate on seed quality in cultivar 'Br-203'.

\begin{tabular}{ccccccc}
\hline Treatment & $\begin{array}{c}\text { FSP } \\
\mathbf{( \% )}\end{array}$ & $\begin{array}{c}\text { TSW } \\
\mathbf{( g )}\end{array}$ & $\begin{array}{c}\text { PP } \\
\mathbf{( \% )}\end{array}$ & $\begin{array}{c}\text { PSY } \\
\mathbf{( k g / h a )}\end{array}$ & $\begin{array}{c}\text { GP } \\
\mathbf{( \% )}\end{array}$ & $\begin{array}{c}\text { PGSY } \\
\text { (kg/ha) }\end{array}$ \\
\hline Closing cut date & & & & & & \\
Uncut & 18.25 & 5.72 & 95.93 & 290.90 & 93.03 & 269.56 \\
15 June & 12.38 & 5.79 & 95.21 & 287.54 & 91.72 & 264.05 \\
1 July & 14.61 & 5.72 & 95.31 & 325.12 & 91.06 & 299.10 \\
15 July & 12.12 & 5.90 & 87.68 & 340.75 & 93.17 & 318.26 \\
CV (\%) & 61.90 & 6.60 & 13.60 & 46.80 & 6.30 & 48.30 \\
N-rate (kg N/ha) & & & & & & \\
0 & 16.40 & $5.90^{\mathrm{ab}}$ & 90.08 & 301.62 & 93.90 & 282.18 \\
50 & 12.17 & $5.98^{\mathrm{a}}$ & 97.36 & 331.58 & 92.28 & 304.43 \\
100 & 14.43 & $5.73^{\mathrm{ab}}$ & 92.62 & 289.13 & 90.72 & 266.32 \\
150 & 14.33 & $5.55^{\mathrm{b}}$ & 94.07 & 321.96 & 92.12 & 298.04 \\
CV (\%) & 64.50 & 8.60 & 13.60 & 64.80 & 5.50 & 65.20 \\
\hline Mean & 14.37 & 5.78 & 93.53 & 311.07 & 92.23 & 287.74 \\
CCD $\times$ N-rate & $\mathrm{ns}$ & $\mathrm{ns}$ & $\mathrm{ns}$ & $\mathrm{ns}$ & $\mathrm{ns}$ & $\mathrm{ns}$ \\
\hline
\end{tabular}

Abbreviations: FSP, filled seed percentage; TSW, thousand seed weight; PP, purity percentage; PSY, pure seed yield GP, germination percentage; PGSY, pure germinated seed yield; ns, non-significant. Note: ${ }^{a, b}$ Means followed by different superscripts in each column indicate significant differences $(p<0.05)$.

Table 13. Correlation coefficients for seed quality and CCD in cultivar 'Br-203'.

\begin{tabular}{ccccccc}
\hline Traits & CCD & FSP & TSW & PP & PSY & GP \\
\hline FSP & $0.9171^{*}$ & & & & & \\
TSW & -0.5491 & -0.7422 & & & & \\
PP & 0.4982 & 0.5872 & $-0.9377^{*}$ & & & \\
PSY & -0.6109 & -0.4277 & 0.5556 & -0.7727 & & \\
GP & 0.4388 & 0.1978 & 0.4964 & -0.5415 & 0.0913 & \\
PGSY & -0.5743 & -0.4116 & 0.5895 & -0.8070 & $0.9972^{* *}$ & 0.1649 \\
\hline
\end{tabular}

Abbreviations: CCD, closing cut date; FSP, filled seed percentage; TSW, thousand seed weight; PP, purity percentage; PSY, pure seed yield; GP, germination percentage; PGSY, pure germinated seed yield. Note: Values without asterisks are not significant, * correlation is significant at the 0.05 level (two-tailed), $p<0.05=0.878339$ and ${ }^{* *}$ correlation is significant at the 0.01 level (two-tailed), $p<0.01=0.958735$.

In the findings in several tropical pasture grasses, $\mathrm{N}$ fertilizer application to seed crops affects yield component dynamics such as tiller increase, number of fertile tillers, florets per spikelet, and seed per head, resulting in higher seed yield and quality [37]. However, in this experiment, all of the measured agronomic traits, except TSW, were not significantly $(p>0.05)$ affected by the variation in N-rate. Average seed yield, seed yield components, and seed quality attributes of cv. 'Br-203' in response to different N-rates are presented in Tables 10 and 12. The addition of $\mathrm{N}$ tends to increase IN and IN/T in Br-203 (Table 10), though no significant difference was observed. This is consistent with a strong positive correlation that was observed between TN, IN, and IN/T and the N-rate (Table 14). 
Table 14. Correlation coefficients of seed yield, seed components and N-rate in cultivar 'Br-203'.

\begin{tabular}{cccccccc}
\hline Traits & N-Rate & TSY & TN & FTN & IN & FTP & IN/T \\
\hline TSY & -0.5385 & & & & & & \\
TN & $0.9845^{* *}$ & -0.4567 & & & & & \\
FTN & 0.5900 & 0.3364 & 0.6823 & & & & \\
IN & $0.9074^{*}$ & -0.2248 & $0.9633^{* *}$ & 0.8406 & & & \\
FTP & -0.0394 & 0.8285 & 0.0880 & 0.7835 & 0.3438 & & 0.5333 \\
IN/T & $0.9771^{* *}$ & -0.6991 & $0.9357^{*}$ & 0.4050 & 0.8068 & -0.2508 & 0.4199 \\
RN/I & 0.6394 & -0.1345 & 0.7618 & 0.7318 & 0.8621 & 0.4927 & 0.0721 \\
SN/R & 0.5845 & 0.1445 & 0.5316 & 0.6348 & 0.5324 & 0.3285 & 0.4921 \\
\hline
\end{tabular}

Abbreviations: N-rate, rate of nitrogen application; TSY, total seed yield; TN, tiller number per square meter; FTN fertile tiller number per square meter; IN, inflorescence number per square meter; FTP, fertile tiller percentage; $\mathrm{IN} / \mathrm{T}$, inflorescence number per tiller; RN/I, raceme number per inflorescence; SN/R, spikelet number per raceme. Note: Values without asterisks are not significant, ${ }^{*}$ correlation is significant at the 0.05 level (two-tailed), $p<0.05$ $=0.878339$ and $^{* *}$ correlation is significant at the 0.01 level (two-tailed), $p<0.01=0.958735$.

The effect of $\mathrm{N}$ on seed quality varies depending on the species and environmental conditions [37]. A negative correlation was observed between seed quality and N-rate in cv. 'Br-203', as shown in Table 15. According to our findings, higher levels of N-rate gradually decreased TSW in cv. 'Br-203'. Even though these results differ from previous studies on $U$. decumbens [21], U. ruziziensis [18], and cv. 'Mulato' [14], they are consistent with those of earlier studies in P. atratum at Pakchong, Thailand [19]. For example, in hybrid Urochloa lines in which an N-rate of $80 \mathrm{~kg} \mathrm{~N} /$ ha was applied, TSW was reduced when compared with an N-rate of $40 \mathrm{~kg}$ N/ha [16]. Meijer and Vreeke [52] reported that average seed weight was reduced at high N-rates because the increase in the proportion of late-developing inflorescences results in lighter seed weight at harvest.

Table 15. Correlation coefficients for seed quality and N-rate in cultivar 'Br-203'.

\begin{tabular}{ccccccc}
\hline Traits & N-Rate & FSP & TSW & PP & PSY & GP \\
\hline FSP & -0.2951 & & & & & \\
TSW & $-0.8789 *$ & -0.1906 & & & & \\
PP & -0.6613 & -0.2844 & 0.7748 & & & \\
PSY & 0.1246 & -0.6624 & 0.1416 & 0.6618 & & \\
GP & -0.6845 & 0.4739 & 0.4161 & 0.6840 & 0.2287 & \\
PGSY & 0.0716 & -0.5615 & 0.1404 & 0.6945 & $0.9917^{* *}$ & 0.3415 \\
\hline
\end{tabular}

Abbreviations: N-rate, rate of nitrogen application; FSP, filled seed percentage; TSW, thousand seed weight; PP purity percentage; PSY, pure seed yield; GP, germination percentage; PGSY, pure germinated seed yield. Note: Values without asterisks are not significant, ${ }^{*}$ correlation is significant at the 0.05 level (two-tailed), $p<0.05=$ 0.878339 and ${ }^{* *}$ correlation is significant at the 0.01 level (two-tailed), $p<0.01=0.958735$.

According to Nakmanee et al. [7], cv. 'Br-203' has adapted well to the conditions in northeastern and northern Thailand, and this cultivar has high agronomic potential, including the ability to tolerate drought conditions. The cultivar appeared to have a sufficient number of inflorescences, racemes, and spikelets, indicating a potential for favorable seed yields. However, this cultivar also produced numerous empty seeds, which decreased seed yields and the low seed-set observed was a crucial weakness of the cultivar as well as hybrid Urochloa grasses, and a poor seed-set could be a common flaw in newly formed apomictic forage grass hybrids $[53,54]$. An early study on cv. 'Mulato II' reported very low seed yields with fewer than $2 \%$ of the spikelets that formed viable seed, likely due to pollen sterility [9]. One reason for low seed setting is thus partly genetic in origin. For example, Risso-Pascotto et al. [55,56] reported that more than $65 \%$ of pollen grains in interspecific hybrids between $U$. ruziziensis and $U$. brizantha were sterile. Specifically, they demonstrated that this sterility had a genetic basis and was due to irregular chromosome segregation, chromosome stickiness, abnormal cytokinesis, and asynchronous meiosis.

In both trials, close cutting is required for seed production in both Urochloa cultivars. Mid-June to early July was the best period for close cutting cv. 'OKI-1', and early-July to 
mid-July was the proper time for close cutting cv. 'Br-203'. This study discovered that $\mathrm{N}$ fertilizer application had no direct effect on seed yield. This is supported by the study on Cenchrus spp., which reported that the amount of $\mathrm{N}$ fertilizer required depends on species, soil type, and rainfall [37]. The low soil fertility, which is caused by a deficiency of other nutrients besides $\mathrm{N}$, affected the plants' responses to $\mathrm{N}$. Once these nutrients are present in sufficient concentrations, the $\mathrm{N}$ response may improve [36]. More often, 100-250 kg $\mathrm{N} /$ ha of crop and a rate of more than $300 \mathrm{~kg} \mathrm{~N} /$ ha caused a reduction in seed yield due to severe plant lodging [37]. Moreover, $\mathrm{N}$ fertilization management can affect the seed yield and quality of tropical forage grasses. The responses of tropical grasses as a function of $\mathrm{N}$ fertilization management may vary between species and cultivars [39]. Additionally, in terms of economic performance and the relationship between seed production and N-rate, the results of this study showed that no $\mathrm{N}$ fertilizer was appropriate for the two novel Urochloa cultivars in northern Thailand. However, further studies should be conducted to confirm these results.

\section{Conclusions}

This study was conducted to evaluate the effects of CCD and N-rate on seed yield and seed quality of two novel cultivars of Urochloa spp. (cv. 'OKI-1' and cv. 'Br-203') so that farmers can utilize information on the agricultural management of these grasses when they are promoted for planting in northern Thailand.

1. No significant mutual interactions were observed between the CCD and N-rate on seed yield, seed yield components, or seed quality in both cultivars.

2. The highest seed yields in $\mathrm{cv}$. 'OKI-1' and cv. 'Br-203' were obtained when the CCD was 1 July and 15 July, respectively.

3. The CCD affected most seed quality attributes, except seed germination percentage (GP) in cv. 'OKI-1'.

4. The CCD in late-June to early-July and early-July to mid-July are recommended for $\mathrm{cv}$. 'OKI-1' and cv. 'Br-203', respectively.

5. The seed yields in cv. 'OKI-1' and cv. 'Br-203' were non-significant in response to the different $\mathrm{N}$-rates in the fertilization timing in our experiment.

Author Contributions: Conceptualization, Y.K., S.T. and W.J.; methodology, W.J., S.T. and R.P.; validation, W.J., Y.I., M.A.H. and Y.K.; formal analysis, W.J.; investigation, Y.K.; resources, Y.K.; data curation, W.J.; writing—original draft preparation, W.J.; writing-review and editing, Y.K., I.N., Y.I. and M.A.H.; visualization, W.J.; supervision, Y.K. and M.A.H.; funding acquisition, Y.K. All authors have read and agreed to the published version of the manuscript.

Funding: This research received no external funding.

Institutional Review Board Statement: Not applicable.

Informed Consent Statement: Not applicable.

Data Availability Statement: Not applicable.

Acknowledgments: The study was part of a collaborative project titled "Evaluation of breeding and promising lines of Urochloa for new varieties" between the Department of Livestock Development, Thailand and the University of the Ryukyus, Japan. The contract research project, "Comprehensive development program for Okinawan strategic pasture grass varieties," provided some funding for the study. The authors express their gratitude to all of the collaborators at both organizations, particularly President Hajime Oshiro of the University of the Ryukyus and the Director of the Department of Livestock Development, Thailand, the Director of the Bureau of Animal Nutrition and Development (BAND), the Director of Lampang ANRDC, and the BAND staff who contributed to this study. We also appreciate the Lampang Rice Seed Center's Director and staff's assistance with this work.

Conflicts of Interest: The authors declare no conflict of interest. 


\section{References}

1. Fisher, M.J.; Kerridge, P.C. The agronomy and physiology of Brachiaria species. In Brachiaria: Biology, Agronomy, and Improvement; Miles, J.W., Maass, B.L., do Valle, C.B., Eds.; CIAT: Cali, Colombia, 1996; pp. 43-52.

2. Rao, I.; Peters, M.; Castro, A.; Schultze-Kraft, R.; White, D.; Fisher, M.; Miles, J.; Lascano, C.; Blümmel, M.; Bungenstab, D.; et al. LivestockPlus-The sustainable intensification of forage-based agricultural systems to improve livelihoods and ecosystem ser-vices in the tropics. Trop. Grassl.-Forrajes Trop. 2015, 3, 59-82. [CrossRef]

3. Cheruiyot, D.; Midega, C.A.O.; Pittchar, J.O.; Pickett, J.A.; Khan, Z.R. Farmers' perception and evaluation of Brachiaria grass (Brachiaria spp.) genotypes for smallholder cereal-livestock production in East Africa. Agriculture 2020, 10, 268. [CrossRef]

4. Kouki, K.; Ishigaki, G.; Akashi, R.; Shimabukuro, H. The newly-bred cultivar production in Brachiaria grass. In (1) Production of the High Seed Yield Strains Using Sexual Tetraploid Ruzigrass 'Miyaokikoku-Ichigou'; Annual Report; Okinawa Prefectural Livestock and Grassland Research Center: Okinawa, Japan, 2014; Volume 52, pp. 73-75.

5. Ishigaki, G.; Gondo, T.; Suenaga, K.; Akashi, R. Induction of tetraploid ruzigrass (Brachiaria ruziziensis) plants by colchicine treatment of in vitro multiple-shoot clumps and seedlings. Grassl. Sci. 2009, 55, 164-170. [CrossRef]

6. Thaikua, S.; Chanpeng, P.; Juntasin, W.; Donsawai, S.; Chuchuay, P.; Kouki, K.; Kawamoto, Y. Effect of ploidy on digestibility and fiber fraction of ruzigrass (Brachiaria ruziziensis). In Proceedings of the 18th Asian-Australasian Animal Production (AAAP) Congress, Sarawak, Malaysia, 1-5 August 2018; p. 434.

7. Nakmanee, G.; Ebina, M.; Shimoda, K.; Thaikua, S.; Srisomporn, W.; Patipan, C.; Suenaga, K.; Ando, S.; Kouki, K.; Ishigaki, G.; et al. A new candidate cultivar of Brachiaria grass 'Br-203' developed with apomixis marker assisted selection, through a collaborative breeding activity of Thailand and Japan. In Proceedings of the 23rd International Grassland Congress, New Dehli, India, 20-24 November 2015; Roy, M.M., Malaviya, D.R., Yadav, V.K., Singh, T., Sah, R.P., Vijay, D., Radhakrishna, A., Eds.; Range Management Society of India: New Dehli, India, 2015.

8. Loch, D.S.; Aviles, R.; Harvey, G.L. Crop management: Grasses. In Forage Seed Production Vol. 2: Tropical and Subtropical Species; Loch, D.S., Ferguson, J.E., Eds.; CABI Publishing: Wallingford, UK, 1999; pp. 159-176.

9. Hare, M.D.; Tatsapong, S.; Saipraset, K. Seed production of two brachiaria hybrid cultivars in north-east Thailand. 2. Closing date defoliation. Trop. Grassl. 2007, 41, 35-42.

10. Cropping Strategies, a Summary of Recent Research Findings: Closing Date in Perennial Ryegrass, Closing Date in Italian Ryegrass. Foundation of Arable Research PO Box 23133, Templeton, Christchurch 8445, New Zealand. Available online: https:/ / www.far.org.nz/assets/files/blog/files/2c6f1d23-3c63-4bf7-8ed2-bb7b5543083f.pdf (accessed on 27 May 2021).

11. Hare, M.D.; Wongpichet, K.; Tatsapong, S.; Narksombat, S.; Saengkhum, M. Method of seed harvest, closing date and height of closing cut affect seed yield and seed yield components in Paspalum atratum in Thailand. Trop. Grassl. 1999, 33, 82-90.

12. Gobius, N.R.; Phaikaew, C.; Pholsen, P.; Rodchompoo, O.; Susena, W. Effects of date of closing cut on seed yield and its components of Andropogon gayanus cv. Kent. Trop. Grassl. 1998, 32, 230-234.

13. Phaikaew, C.; Pholsen, P. Ruzigrass (Brachiaria ruziziensis) seed production and research in Thailand. In Proceedings of the Third Meeting of Regional Working Group on Grazing and Feed Resources of Southeast Asia, Khon Kaen, Thailand, 31 January-6 February 1993; pp. 165-173.

14. Nakmanee, G.; Phaikaew, C.; Thinnakorn, S. Effect of closing cut date and nitrogen rates on seed yield and seed quality of Mulato grass (Brachiaria ruziziensis $\times$ Brachiaria brizantha). In Annual Report; Bureau of Animal Nutrition Development, Department of Livestock Development: Bangkok, Thailand, 2007; pp. 199-210.

15. Phaikaew, C.; Intaramanee, S.; Tewahudee, P.; Boonpakdee, W.; Suriyajantrathong, W.; Senakulp, U.; Nakmanee, G.; Pholboon, P. Effect of cutting periods on seed yields of ruzi grass (Brachiaria ruziziensis). In Annual Report; Bureau of Animal Nutrition Development, Department of Livestock Development: Bangkok, Thailand, 1985; pp. 106-116.

16. Bouathong, C.; Hare, M.; Losirikul, M.; Wongpichet, K. Effect of nitrogen-rates on plant growth, seed yield and seed quality of three lines of Brachiaria hybrid grass. Khon Kaen Agr. J. 2011, 39, 295-306.

17. Satjipanon, C.; Nakmanee, K.; Maneedool, C.; Boonrat, J. Effect of defoliation management and rate of nitrogen on seed yield and seed quality of Ruzi grass (Brachiaria ruziziensis). In Annual Report; Bureau of Animal Nutrition Development, Department of Livestock Development: Bangkok, Thailand, 1987; pp. 195-215.

18. Wongsuwan, N. Effects of Cutting, Nitrogen, Closing Date and Water on Herbage and Seed Production in Ruzi Grass (Brachiaria ruziziensis Germain and Everard). Ph.D. Thesis, Massey University, Palmerston North, New Zealand, 1999.

19. Phaikaew, C.; Intarit, S.; Tudsri, S.; Tsuzuki, E.; Numaguchi, H.; Ishii, Y. Effects of time of final closing cut on seed yield and seed quality of Paspalum atratum in Thailand. Trop. Grassl. 2002, 36, 150-158.

20. De Lima, B.G.; Verzignassi, J.R.; Fernandes, C.D.; Do Valle, C.B.; Macedo, M.C.M.; De Liborio, C.B.; Monterio, L.C. Productivity and quality of Brachiaria brizantha B4 seeds in function of nitrogen doses. Ciênc. Rural. 2016, 46, 1566-1571.

21. Canto, M.W.; Pancera, E.J., Jr.; Barth Neto, A.; Bremm, C.; Vier, P.U.; Costa, A.C.S. Effects of nitrogen fertilization and irrigation on seed yield and yield components of signal grass (Urochloa decumbens). Crop Pasture Sci. 2020, 71, $294-303$.

22. Adjolohoun, S.; Bindelle, J.; Adandedjan, C.; Toléba, S.S.; Houinato, M.; Kindomihou, V.; Nonfon, W.R.V.; Sinsin, B. Influence de l'écartement et de la fertilisation azotée sur le rendement et la qualité des semences de Brachiaria ruziziensis en climat tropical sub-humide. Fourrages 2013, 216, 339-345.

23. Group of Soil Series. Available online: http://oss101.ldd.go.th/osr_data\&service/OSR_PDF/TB_SSK_Distribute/P_SSK529.pdf (accessed on 14 November 2021). 
24. ISTA (International Seed Testing Association). International Rules for Seed Testing Edition 2011; The International Seed Testing Association: Bassersdorf, Switzerland, 2011.

25. The R Project for Statistical Computing. Available online: https:/ / www.R-project.org/ (accessed on 14 November 2021).

26. Handbook of Soil Chemical Analysis. Available online: http:/ / www.ldd.go.th/PMQA/2553/Manual/OSD-03.pdf (accessed on 14 November 2021).

27. Rao, I.M.; Kerridge, P.C.; Macedo, M. Nutritional requirements of Brachiaria and adaptation to acid soils. In Brachiaria: Biology, Agronomy, and Improvement; Miles, J.W., Maass, B.L., do Valle, C.B., Eds.; Centro International de Agricultura Tropical (CIAT): Cali, Colombia, 1996; pp. 53-71.

28. Boonman, J.G. Determinants of seed yield. In On the Seed Production of Tropical Grasses in Kenya; Leniger, H.A., Ed.; Centre for Agricultural Publishing and Documentation: Wageningen, The Netherlands, 1973; pp. 2-9.

29. Stür, W.W.; Hopkinson, J.M.; Chen, C.P. Regional experience with Brachiaria: Asia, the South Pacific, and Australia. In Brachiaria: Biology, Agronomy, and Improvement; Miles, J.W., Maass, B.L., do Valle, C.B., Eds.; Centro International de Agricultura Tropical (CIAT): Cali, Colombia; CNPGC/EMBRAPA: Grande MS, Brazil, 1996; pp. 258-271.

30. Brachiaria Hybrid. In: Pastures Australia. Available online: https://keys.lucidcentral.org/keys/v3/pastures/Html/Brachiaria_ hybrid.htm (accessed on 14 November 2021).

31. Nadew, B.B. Effects of climatic and agronomic factors on yield and quality of bread wheat (Triticum aestivum L.) seed: A review on selected factors. Adv. Crop Sci. Technol. 2018, 6, 356.

32. Wongsuwan, N. Seed Production Studies in Ruzi Grass (Brachiaria ruziziensis Germain and Everard). Master's Thesis, Massey University, Palmerston North, New Zealand, 1994.

33. Deinum, B.; Dirven, J.G.P. Climate, nitrogen and grass. 5. Influence of age, light intensity and temperature on the production and chemical composition of Congo grass (Brachiaria ruziziensis Germain et Everard). Neth. J. Agri. Sci. 1972, 20, 125-132. [CrossRef]

34. Galdos, M.V.; Brown, E.; Rosolem, C.A.; Pires, L.F.; Hallett, P.D.; Mooney, S.J. Brachiaria species influence nitrate transport in soil by modifying soil structure with their root sytem. Sci. Rep. 2020, 10, 5072. [CrossRef]

35. Jones, C.A.; Koenig, R.T.; Ellsworth, J.W.; Brown, B.D.; Jackson, G.D. Management of Urea Fertilizer to Minimize Volatilization; The U.S. Department of Agriculture (USDA), Steele, D.L., Eds.; Extension Service; Montana State University: Bozeman, MT, USA, 2007; pp. 1-12.

36. Sun, X.; Luo, N.; Longhurst, B.; Luo, J. Fertiliser nitrogen and factors affecting pasture responses. Open Agric. J. 2008 , 2, 35-42. [CrossRef]

37. Gbenou, B.; Adjolohoun, S.; Houndjo, D.B.M.; Ahoton, L.; Aliou Saidou, A.; Houinato, M.; Seibou Toleba, S.; Sinsin, B.A. Practical aspects of grass forage seed production and quality with particular reference to planting row spacing and nitrogen fertilization in tropical regions: A review. Int. J. Biol. Chem. Sci. 2018, 12, 508-518. [CrossRef]

38. Brunse, H.; Watkin, B.R. Tropical pasture management for grass seed production. In Proceedings of the Lectures and Findings of Symposium and Workshop on Forage Grass Seed Production, Muaklek, Thailand, 28 October-8 November 1991; Brunse, H., Sukpituksakul, P., Eds.; Bangkok, Thailand, 1992; pp. 9-16.

39. Catuchi, T.A.; Soratto, R.P.; Francisquini Júnior, A.; Guidorizzi, F.V.C.; Tiritan, C.S. Nitrogen management of forage grasses for nutrition, seed production, and nutrients in residual straw. Pesqui. Agropecu. Bras. 2019, 54, e00114. [CrossRef]

40. Dida, M.F.; Lemore, A.A.; Seid, K.A. Effect of nitrogen level on herbage and seed yield of Rhodes grass (Chloris gayana). Int. J. Agron. 2021, 2021, 5540596.

41. Canto, M.W.; Almeida, G.M.; Costa, A.C.S.; Neto, A.B.; Scaliante, J.R., Jr.; Orlandini, C.F. Seed production of 'Mombasa' grass subjected to different closing cut dates and nitrogen rates. Pesq. Agropec. Bras. 2016, 51, 766-775. [CrossRef]

42. Joaquín, T.M.B.; Gómez, V.A.; Ramos, J.J.A.; Aranda, I.E.M.; Pérez, A.J.A.; Joaquín, C.S. Yield and quality of guinea grass seed cv. Mombaza at different pre-cut dates. Rev. Mex. Cienc. Agric. 2020, 24, 191-200.

43. Lopes, R.R.; Ost, H.J.; Souza, C.H.L.; Franke, L.B. Management of consecutive cuts in the production and quality of wintergreen paspalum seeds. Rev. Bras. Zootec. 2016, 45, 587-595. [CrossRef]

44. Boonman, J.G. Experimental studies on seed production of tropical grasses in Kenya. 2. Tillering and heading in seed crops of eight grasses. Neth. J. Agri. Sci. 1971, 19, 237-249. [CrossRef]

45. Humphreys, L.R.; Riveros, F. Tropical Pasture Seed Production; FAO Plant Production and Protection Paper; Publications Division, Food and Agriculture Organization of the United Nations: Rome, Italy, 1986; 216p.

46. Hill, M.J.; Loch, D.S. Achieving potential herbage seed yields in tropical regions. In Proceedings of the XVII International Grassland Congress, Palmerston North, New Zealand, 8-21 February 1993; pp. 1629-1635.

47. Martiniello, P.; Silva, J.A.T. Physiological and bioagronomical aspects involved in growth and yield components. of cultivated forage species in mediterranean environments: A review. Eur. J. Plant Sci. Biotechnol. 2011, 5, 64-68.

48. Awad, A.; Hafiz, S.; Hammada, M.S.; El-Nouby, A.; El-Hendawy, S. Grain yield production of Sudan grass (Sorghum sudanense (Piper) Stapf) as influenced by cutting numbers, potassium rates, and intrarow spacing in a semiarid environment. Turk. J. Agric. For. 2013, 37, 657-664. [CrossRef]

49. Mishra, M.L.; Chatterjee, B.N. Seed production in the forage grasses Pennisetum polystachyon and Andropogon gayanus in the India tropics. Trop. Grassl. 1968, 2, 51-56.

50. Kumar, D.; Dwivedi, G.K.; Singh, S.N. Seed yield and quality of buffel grass (Cenchrus ciliaris) as influenced by row spacing and fertilizer level. Trop. Grassl. 2005, 39, 107-111. 
51. Langer, R.H.M. Growth of the grass plant in relation to seed production. In Herbage Seed Production: Proceedings of a Conference at Lincoln College, Canterbury, New Zealand, 13-15 November 1979; Lancashire, J.A., Ed.; Grassland Research and Practice Series No.1; New Zealand Grassland Association (Inc.): Palmerston North, New Zealand, 1980; pp. 6-11. Available online: https: //www.grassland.org.nz/publications/nzgrassland_publication_539.pdf (accessed on 15 November 2021).

52. Meijer, W.J.M.; Vreeke, S. Nitrogen fertilization of grass seed crops as related to soil mineral nutrition. Neth. J. Agri. Sci. 1988, 36, 375-385. [CrossRef]

53. Hare, M.D.; Pizarro, E.A.; Phengphet, S.; Songsiri, T.; Sutin, N. Evaluation of new hybrid Brachiaria lines in Thailand. 2. Seed production. Trop. Grassl.-Forrajes Trop. 2015, 3, 94-103. [CrossRef]

54. Miles, J.W.; Hare, M.D. Plant breeding and seed production of apomictic tropical forage grasses. In Seed Production in the Northern Light, Proceedings of the Sixth International Herbage Seed Conference, Grimstad, Norway, 18-20 June 2007; pp. 74-81.

55. Risso-Pascotto, C.; Pagliarini, M.S.; Do Valle, C.B.; Jank, L. Asynchronous meiosis in an interspecific hybrid of Brachiaria ruziziensis and B. brizantha. Plant Cell Rep. 2004, 23, 304-310. [CrossRef]

56. Risso-Pascotto, C.; Pagliarini, M.S.; Do Valle, C.B. Meiotic behavior in interspecific hybrids between Brachiaria ruziziensis and Brachiaria brizantha (Poaceae). Euphytica 2005, 145, 155-159. [CrossRef] 